\title{
Assessing the Impact of Existing and Future Water Demand on Economic and Environmental Aspects (Case Study from Rift Valley Lake Basin: Meki-Ziway Sub Basin), Ethiopia
}

Abebe Guadie Shumet* and Kassa Tadele Mengistu

Arba Minch University, Ethiopia

\begin{abstract}
In the development of water resource projects there is an increase and extensive use of water resources, which causes exploitation of the existing systems and ecosystem of the natural environment. The Water Evaluation and Planning (WEAP) model is used to assess water demand by considering the existing development situation and future water resources development with scenarios analysis in the study area (Ziway Meki Sub Basin, Ethiopia). Three different development scenarios were developed to simulate water use at demand sites. In the simulations, the catchment was divided into 5 main sub-catchments where the supply and demand nodes were spatially located The competing water sectors were irrigation development, domestic users, soda ash industry and environmental flow requirements. Hydro Meteorological data, net evaporation from Lake Reservoir, and monthly water demand from user sectors were the basic inputs to the model. The results of the reference scenario were validated using observed flows. Accordingly, the simulation result revealed that the total average annual inflow volume into the study area is declining significantly for reference scenarios and water availability is limited in the months of January $\left(17 \mathrm{Mm}^{3}\right)$ and December $\left(171 \mathrm{Mm}^{3}\right)$ while in the other months the availability is efficient and all users have $100 \%$ coverage. Except Langano irrigation site that have between $33.33 \%$ to $86.5 \%$ coverage in average during the month of Feb to May $\left(2.57 \mathrm{Mm}^{3}\right)$ and April in Bulbula $95.2 \%$ coverage, others get full coverage. The minimum reliability observed mostly in the ongoing and likely future development scenarios at Bulbula irrigation demand sites which have $92.11 \%$ and $66.67 \%$ reliability in Langano irrigation demand sites throughout all development scenarios. On the other hand, in Sher-Ethiopia expansion, $51.75 \%$ reliability is observed in ongoing and likely future development scenarios and in demand site of Katar irrigation diversion and Meki irrigation from dam $51.75 \%$ is observed in likely future development scenarios.
\end{abstract}

Keywords: Central rift valley; WEAP model; Water allocation; Demand sites; Demand coverage; Reliability; Scenario analysis

\section{Introduction}

\section{Background}

The rising demands for water resources will make its allocation a struggle in the near future. Water consumption has increased about sevenfold since the beginning of the twentieth century [1]. This is especially true for developing countries, particularly in Ethiopia, where the need to enhance agricultural productivity faces diminishing water supplies for agriculture owing to rapid industrialization and ever-increasing municipal needs. Valipour [2] showed that $54 \%$ of the world is suitable for rain-fed agriculture whereas $80 \%$ of agricultural production is from rain-fed areas.

The Ethiopian Central Rift Valley (CRV) is part of the Great African Rift. It is situated in the administrative regions of Oromiya and the Southern Nations Nationalities and Peoples Region (SNNPR), and covers an area of approximately $10,000 \mathrm{~km}^{2}$. The total population of the CRV is approximately 1.5 million. The Central Rift Valley consists of a chain of lakes, streams and wetlands. Being a closed basin, the CRV is one of the environmentally very vulnerable areas in Ethiopia [3]. Recently, smallholder irrigation schemes have been implemented in the area. This creates shortage of water resources for irrigation and processing purposes. The increasing pressure on land and water resources intensifies conflicts between various stakeholders. The associated increase in water extraction/abstraction from surface water and groundwater resources puts an increasing claim on scarce water resources in the area understanding of the existing and future water demand with negative impact on economic development and environment of the basin enables to identify and design hearty development options.

In Ethiopia, the uneven spatial and temporal occurrence and distribution of the water resources among others have been considered as the major factors affecting the development and management of water sector of the country [4]. Among the different water regimes of the country, the Central Ethiopian Rift Valley with Lakes Ziway, Langano, Abyata and Shalla is one of those rain fall deficit areas where the surrounding agro climatic and geological factors are believed to have significant impact on the hydrological system [5].

The Ziway Meki sub basin in the central rift valley lakes has the greatest potential for effective development owing to its favorable agro climatology and socio-economic conditions that attract investments mainly in the agricultural sector.

Recently, policies of the Ethiopian government strongly support export-oriented irrigated horticulture and private large scale floriculture as a means to increase foreign exchange earnings and employment

${ }^{*}$ Corresponding author: Shumet AG, Arba Minch University, Ethiopia, Tel: +779237407; Fax: +779237407; E-mail: s.abe2004@gmail.com

Received March 27, 2016; Accepted April 28, 2016; Published May 05, 2016

Citation: Shumet AG, Mengistu KT (2016) Assessing the Impact of Existing and Future Water Demand on Economic and Environmental Aspects (Case Study from Rift Valley Lake Basin: Meki-Ziway Sub Basin), Ethiopia. Int J Waste Resour 6: 223. doi:10.4172/2252-5211.1000223

Copyright: (c) 2016 Shumet AG, et al. This is an open-access article distributed under the terms of the Creative Commons Attribution License, which permits unrestricted use, distribution, and reproduction in any medium, provided the original author and source are credited. 
Citation: Shumet AG, Mengistu KT (2016) Assessing the Impact of Existing and Future Water Demand on Economic and Environmental Aspects (Case Study from Rift Valley Lake Basin: Meki-Ziway Sub Basin), Ethiopia. Int J Waste Resour 6: 223. doi:10.4172/2252-5211.1000223

opportunities. The Central Rift Valley is a region in Ethiopia where such policies have resulted in large scale investments in floriculture greenhouses and in a strong growth in smallholder irrigation schemes. The associated increase in irrigation water extraction from surface water and groundwater resources puts an increasing contestation over scarce water resources in the area.

Despite its name the Rift Valley Lake Basin does not have significant water resources [6]. This is the primary constraint to the development of the Rift Valley Lake Basin. Most lakes are terminal, meaning they have no surface outlet. This makes them highly vulnerable to changes in water use regimes and environmentally sensitive. Moreover, all the lakes, with the exception of Lake Ziway, are alkaline/saline and cannot be used for drinking or irrigation without costly desalination and the perennial rivers that are drained to the lakes are not efficiently used and managed [7]. Being able to assess the future scenarios and the ability of the basin to satisfy its future water demands in irrigation and its impact in economic development and the environment is crucial in order to plan for the future and make wise decisions.

In order to guarantee the sustainable development in the environment and economic development in the Central Rift Valley, a proper assessment of the existing and future water demand by using a scenario analysis and proposing proper management of such water resources becomes very essential. A Scenarios Analysis approach has been selected as the most appropriate approach to meet this. These assessments are done by using a computer based modeling tool, which are the WEAP model developed by the Stockholm Environment Institute.

The general objective of this research is to assess and identify the existing and future water demand of the user sectors and their related impacts in hydrology, environmental and economic development of the Central Rift Valley Lake Basin, Ethiopia and propose the management strategies for the present and possible future scenarios.

\section{Description of the Study Area}

\section{Location}

The Ziway Meki Sub basin (Ethiopian central rift valley lake basin) is part of the great Africanrift valley and located about $150-160 \mathrm{~km}$ south of the capital city, Addis Ababa, Ethiopia between $38^{\circ} 00^{\prime}-39^{\circ} 30^{\prime}$ east longitude and $7^{\circ} 00^{\prime}-8^{\circ} 30^{\prime}$ north latitude (the northern most rift valley lakes of Ethiopia), encompasses three large lakes, i.e., Lake Ziway, Abiyata and Langano, with three major rivers, i.e., Bulbula, Meki and Katar.

\section{Materials and Methods}

The methodology in this study includes office and field level investigation of the study area and applying methods and techniques for data analysis. In the study meteorological, hydrological, and water resources data were used. Rainfall, climate, stream flow and water demand for irrigation schemes were necessary and collected from Ethiopian Ministry of Water Resources, National Meteorological Service Agency, and Oromia Regional Offices and Adami Tullu district offices in Ziway. The decision made from the various constraints will affect both the state of water resources and the demands in the catchment. This is revisited through a cyclic loop from the modeling results until a specific objective is met.

\section{Hydrology and water resources models}

Modeling has become an essential tool in modern world of water management, used extensively and plays an important auxiliary role in fulfilling the core tasks of water management, in policy preparation, operational water management and research, and in the collection of basic data (monitoring).

There are several programs that are designed to simulate water development and management policies in river basins. Each of these programs is based on a node-link network representation of the water resource system being simulated. All contain menu-driven graphicsbased interfaces that facilitate user interaction [8]. These programs are appropriate for use in shared vision exercises involving stakeholder involvement in model building and simulations. Some of these models include: River Basin Simulation Model RIBASIM, MIKE Basin, Water Balance Model (WBalMo) MULti-sectoral, Integrated and Operational Decision Support System (MULINO-DSS), and Water Evaluation and Planning System (WEAP).

This study applied WEAP21 in the Ziway Meki catchment in Ethiopian Central Rift Valley. The model was preferred to others because of its robustness and ease of use depending on data availability. The model can perform both lumped to distributed catchment hydrological simulation and can handle aggregated to disaggregated water management demands of various sectors [9]. The system is therefore appropriate for studying catchments with minimum to moderate data availability. Given the cost implication and data availability in the catchment, the model was selected for the purposes of this study. In other words, based upon the following criteria, WEAP was selected to perform water demand and resources assessment and management modeling, since it meets the criteria requirements such as: WEAP can be used at different levels spatially and temporarily; Easy to use with a friendly interface; Recently, WEAP received a great deal of attention where it is being applied at national and international levels; Capable to build and compare scenarios, Priority-based water allocation system, Enable stakeholders to get involved in management procedures through interactive data-driven model [10]. This will increase public awareness and acceptance and enable to assess and evaluate the economical and environmental aspects of the basin, watershed and catchment at different level.

WEAP is distinguished by its integrated approach to simulating water systems and by its policy orientation. WEAP places the demand side of the equation-water use patterns, equipment efficiencies, re-use, prices and allocation-on an equal footing with the supply side-stream flow, groundwater, reservoirs and water transfers. As a database, WEAP provides a system for maintaining water demand and supply information. As a forecasting tool, WEAP simulates water demand, supply, flows, and storage, and pollution generation, treatment and discharge. As a policy analysis tool, WEAP evaluates a full range of water development and management options, and takes account of multiple and competing uses of water systems. It operating at a monthly step on the basic principle of a water balance, WEAP is applicable to municipal and agricultural systems, single catchments or complex trans boundary river systems and address a wide variety of issues like Sectoral demand analyses, water conservation, water rights and allocation priorities, groundwater and stream flow simulations, reservoir operations, hydropower generation, pollution tracking, ecosystem requirements, vulnerability assessments, and project benefit-cost analyses.

\section{Methods of Data Analysis}

The Water Resources System Simulation modeling helps to understand the relationship between available water resources and 
Citation: Shumet AG, Mengistu KT (2016) Assessing the Impact of Existing and Future Water Demand on Economic and Environmental Aspects (Case Study from Rift Valley Lake Basin: Meki-Ziway Sub Basin), Ethiopia. Int J Waste Resour 6: 223. doi:10.4172/2252-5211.1000223

Page 3 of 14

the demand for those resources under existing conditions and under future development scenarios.

The modeling of a watershed using the WEAP consists of the following steps

- Definition of the study area and time frame.

- Creation of the current account.

- Creation of scenarios.

- Evaluation of the scenarios.

With WEAP, first Current Account of the water system under study is created. Then, based on a variety of economic, demographic, hydrological, and technological trends a "reference" scenario projection is established, referred to as a Reference Scenario. Then one or more policy scenarios are developed with alternative assumptions about future developments. The scenarios can address a broad range of "what if" questions. These scenarios may be viewed simultaneously in the results for easy comparison of their effects on the water system. The model simulation is structured as a set of scenarios with monthly time steps. WEAP21 solves the water allocation problem by a linear programme with the objective of maximizing demand node satisfaction constrained by water availability, demand priority, supply priority and proximity to supply.

\section{Annual demand in weap algorithm} Rate $\mathrm{Br}$ )

Annual Demand DS $=\sum B r($ Total Activity LevelBr $\times$ Water Use

Total Activity LevelBr $=$ Activity LevelBr $\times$ Activity LevelBr' $\times$ Activity LevelBr" $\times$ Monthly Demand DS, $\mathrm{m}=$ Monthly Variation Fraction DS, $\mathrm{m} \times$ Adjusted Annual Demand DS

Monthly Supply Requirement DS, $\mathrm{m}=($ Monthly Demand DS, $\mathrm{m} \times$ $(1$ - Reuse Rate DS $) \times 1$ - DSM Savings DS) $) /(1$ - Loss Rate DS $)$.

\section{Catchments delineation}

The river system was schematized from an ArcView GIS layer. The runoff from the catchment nodes in WEAP21 represented the head flow of the streams. In this study, Arithmetic Mean method was used to generate aerial rainfall over the catchment. The method assumes that the recorded rainfall in a gauge is representative for the area halfway to the adjacent gauges. The areal rainfall was estimated using arithmetic mean for the selected period of 1980 to 2007 (Sixteen rainfall stations within the catchment had comprehensive data of monthly precipitation for 1980 to 2007 were used). The Arithmetic mean method is acceptable where a repaid estimate is required and for areas where either the gauges are or the precipitation is fairly uniformly distributed, and WMO, anual points out that rainfall values are assumed to be applicable to area covers up to $25 \mathrm{~km}^{2}$ without reduction.

- Average monthly values of monthly Potential Evapotranspiration.

- Penman-Monteith method is recommended as the sole standard method for definition and computation of the reference Evapotranspiration (FAO irrigation and drainage paper 56).

- Aridity correction factor used for open water evaporation (1.2).

- While Kc coefficients were obtained from the FAO drainage paper [11].
- Linear population growth, Tennat method, and FAO rainfall runoff method were used in WEAP.

The FAO-Rainfall-runoff method in WEAP21 was used to simulate catchment processes (runoff). This method defines land use by crop coefficients, Kc, catchment area and effective precipitation while the climate is defined by precipitation and reference evapotranspiration, ETo. According to FAO Irrigation and Drainage paper 56, the conversion of ETo to evaporation of open water, with depth higher than $5 \mathrm{~m}$, clear of turbidity, in temperate climate, would be varied between 0.65 and 1.25. For Ethiopia, the aridity correction factor was estimated to be 1.2 [12]. Open water evaporation is about $10-20 \%$ higher than evapotranspiration. The Ziway lake evaporation is estimated by multiplying the Ziway evapotranspiration by 1.15 (Figure 1).

\section{Demand sites and supply sources}

A demand site is best defined as a set of water users that share a physical distribution system, that are all within a defined region, or that share an important withdrawal supply point and the user-defined priority system determines the order of allocations to demand sites.

Water demand is defined as the volume of water required by users to satisfy their needs. In a simplified way it is often considered equal to water consumption, although conceptually the two terms do not have the same meaning. This is because in some cases, especially in rural parts of Ethiopia, the theoretical water demand considerably exceeds the actual consumptive water use

The water demand per site is calculated with the total area (in hectares)/or Total Activity level/and the annual water demand per unit of area $\left(\mathrm{m}^{3} / \mathrm{ha}\right)$ or person/Capita/as well as the together with the monthly variations (Table 1 ). Sites were given a priority according to their importance (higher priority for Domestic and Environmental requirements according to Ethiopian water resource management policy, 1999). It is also supposed to that $20 \%$ of the flow derived for each sector returns to the river, as filtrations.

Estimates of current irrigation and domestic demand were derived from feasibility studies and design documents. The future water demands for the proposed projects were assumed to be same as current and weighed based on project situation (e.g., for irrigation projects water demand was weighed based on future command area). Monthly gross irrigation water requirement was derived from the Rift valley Lake Basin Master plan and feasibility study documents based on their availability.

From Meki and Katar river about $4.7 \mathrm{Mm}^{3} /$ year and $9.8 \mathrm{Mm}^{3} /$ year are diverted to irrigate 388 ha and 856 ha of land respectively. Presently direct pumpage from Lake Ziway is about $25 \mathrm{Mm}^{3} /$ year for irrigating about 2000 ha. Pumped water for irrigation from Bulbula River is amounted to $13.9 \mathrm{Mm}^{3} /$ year for irrigating 1095 ha. Main tributary rivers of Lake Langano are diverted for irrigation of 830 ha amounting to $10.5 \mathrm{Mm}^{3}$ /year. Soda Ash plant is expected to pump about $7.5 \mathrm{Mm}^{3} /$ year from Lake Abyata. Water supply demand of Ziway and Bulbula town are also taken into account. Crop types grown vary from year to year: onion, vegetables and maize often take the largest share (Table 2).

The Demand abstraction nodes were spatially located along the river system. The demand was classified as domestic, irrigation and industrial with reducing order of allocation priority respectively. Demand sites-Irrigation, industrial and water supply schemes are combined into seven groups for setting up of the model (Figures 2 and $3)$.

- Meki river diversion irrigation, 


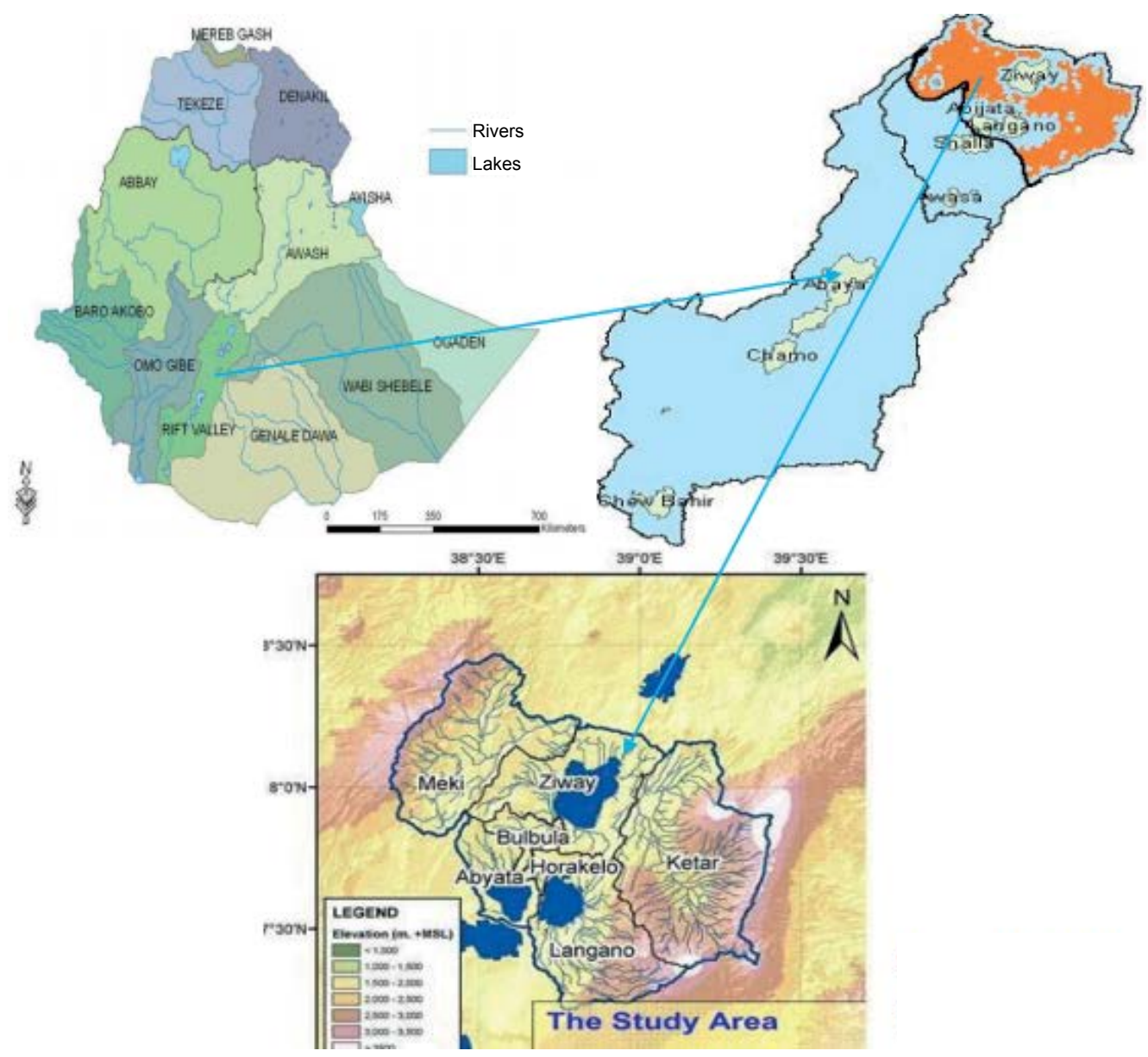

Figure 1: Location and basin map of the study.

\begin{tabular}{|c|c|c|c|c|}
\hline \multirow{2}{*}{ Demand sites } & Required water allocation & Total area/ activity level & Required water allocation & priority \\
\hline & I/s/ha & ha & $\mathrm{m}^{3} / \mathrm{ha}\left(\mathrm{m}^{3} /\right.$ person$)$ & - \\
\hline DS1=Meki irrg & 0.25 & 388 & 12087 & 2 \\
\hline DS2=Katar irrg & 0.18 & 856 & 11483 & 2 \\
\hline DS3=Ziway irrg & 0.25 & 2000 & 12691 & 2 \\
\hline DS4=Langano irrg & 0.25 & 830 & 12691 & 2 \\
\hline DS5=Bulbula irrg & 0.25 & 1095 & 12691 & 2 \\
\hline DS6=Soda Ash & - & 50,000 ton & $150 \mathrm{~m}^{3} /$ tone & 3 \\
\hline DS7=Sher Ethio & 0.25 & 500 & 14600 & 3 \\
\hline DS8=ZWS & - & 43,660 (person) & 32.8 & 1 \\
\hline DS9=BWS & - & 5,000 (person) & 32.8 & 1 \\
\hline
\end{tabular}

Hint: DS1: Demand Site 1; ZWS: Ziway Water Supply; BWS: Bulbula Water Supply

Notes: The total areas for irrigation schemes are lumped as sum of each as together with demand sites and their duties are averaged to simplify the complexity of the calculation procedures

Table 1: Existing demand sites for current scenarios.

- Katar river diversion irrigation,

- Lake Ziway Pumped irrigation \& Ziway Water supply,

- Bulbula river pumped irrigation,

- Langano lake tributary rivers diversion irrigation,

- Bulbula town water supply,

- Soda Ash factory pumped scheme form Lake Abyata.

\section{Model configuration and input data analysis}

Scenario development and model configuration: A scenario can be defined as a plausible description of how the future may develop, based on a coherent and internally consistent set of assumptions about key relationships and driving forces. Scenarios are neither predictions nor forecasts. Since it is not possible to predict exactly how the water demands and other factors that affect water resources are going to change in the future it was decided to use scenarios in the current study. 
Citation: Shumet AG, Mengistu KT (2016) Assessing the Impact of Existing and Future Water Demand on Economic and Environmental Aspects (Case Study from Rift Valley Lake Basin: Meki-Ziway Sub Basin), Ethiopia. Int J Waste Resour 6: 223. doi:10.4172/2252-5211.1000223

Page 5 of 14

\begin{tabular}{|c|c|c|c|}
\hline $\begin{array}{l}\text { Irrigable area (ha) } \\
\text { (Total activity level) }\end{array}$ & $\begin{array}{c}\text { Required water allocation/ } \\
\text { Estimated annual gross water } \\
\text { demand }\left(\mathrm{Mm}^{3}\right)^{+}\end{array}$ & Demand sites & Stage of development \\
\hline 3800 & $22.3 \mathrm{Mm}^{3}$ & Katar dam & Feasibility study on going \\
\hline 5000 & $39.4 \mathrm{Mm}^{3}$ & Meki dam & Feasibility study on going \\
\hline \multirow{2}{*}{15,000} & \multirow{2}{*}{$73.32 \mathrm{Mm}^{3}$} & Ziway pressurized & \multirow{2}{*}{ feasibility study completed } \\
\hline & & irrigation scheme & \\
\hline \multirow{2}{*}{5000} & \multirow{2}{*}{$39.4 \mathrm{Mm}^{3}$} & Ziway Katar & \multirow{2}{*}{ Identification } \\
\hline & & diversion & \\
\hline & & $\begin{array}{l}\text { +Demands estimated though crop water modeling. Where a range of demands } \\
\text { is presented this reflects alternative cropping patterns. }\end{array}$ & \\
\hline
\end{tabular}

Table 2: Planned irrigation developments in Ziway Meki sub basin $[6,12,14]$.

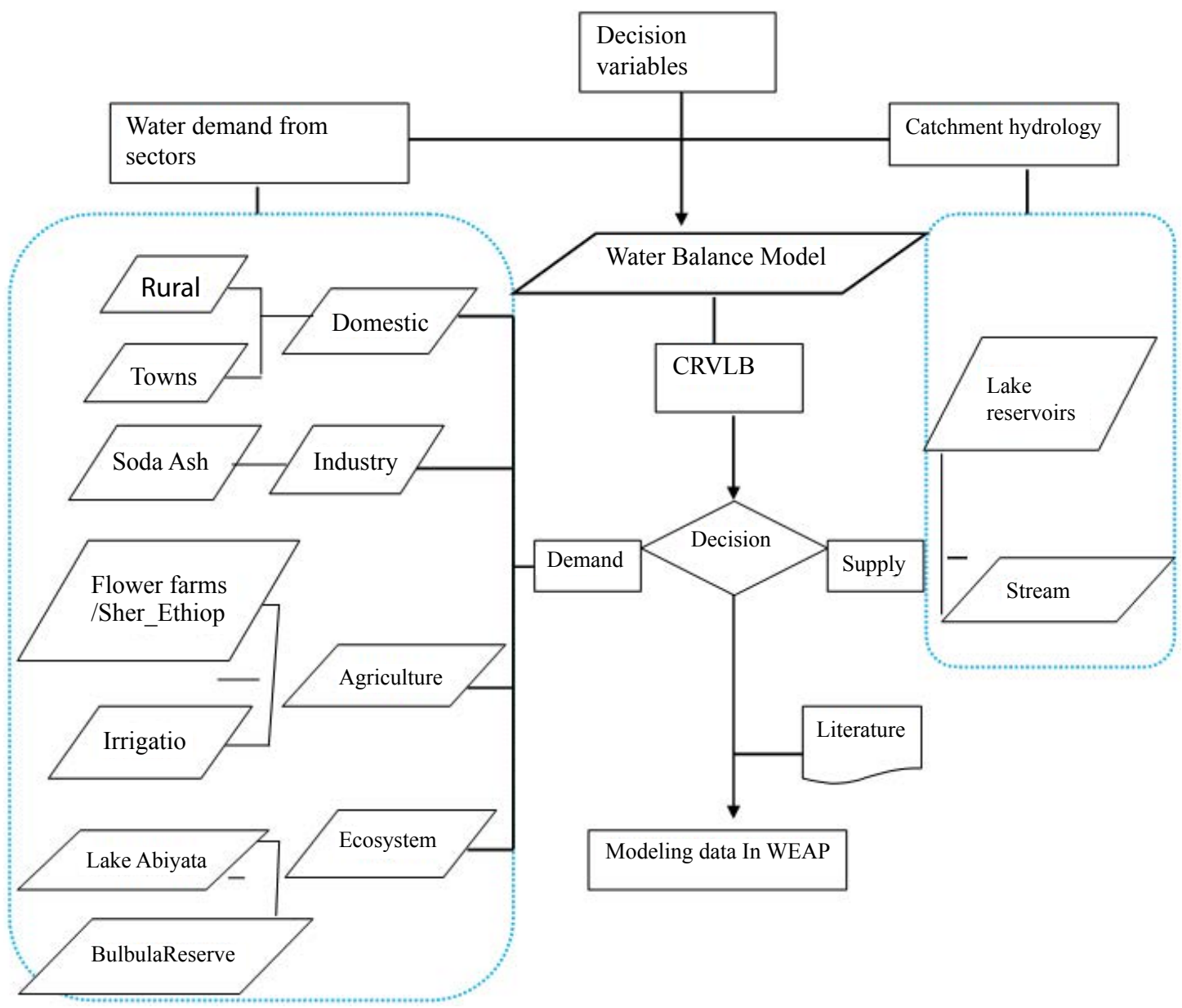

Figure 2: The conceptual framework of the study.

Scenarios are self-consistent story-lines of how a future system might evolve over time in a particular socio-economic setting and under a particular set of policy and technology conditions. Sets of scenarios were developed to account for possible changes in the evolution of the water demands.

The reference scenario is the base scenario that uses the actual data, to help in understanding the best estimates about the studied period. For this scenario the existing data sets on the study area were used. These data input in WEAP is structured according to the schematic set-up of the catchment and is the base scenario for other scenarios and any sub-scenarios that required. These were done in the following steps
- The model is first configured to simulate a base line year or current situation scenario, for which the water availability and demands can be confidently determined.

- What if scenario analyses were built and the simulation was done for 2007 to 2025.

- The scenarios are built on the data of the preceding scenario.

- The following scenarios were therefore created based on the reference scenario.

- Development of the Reference Scenarios (2008-2025). 


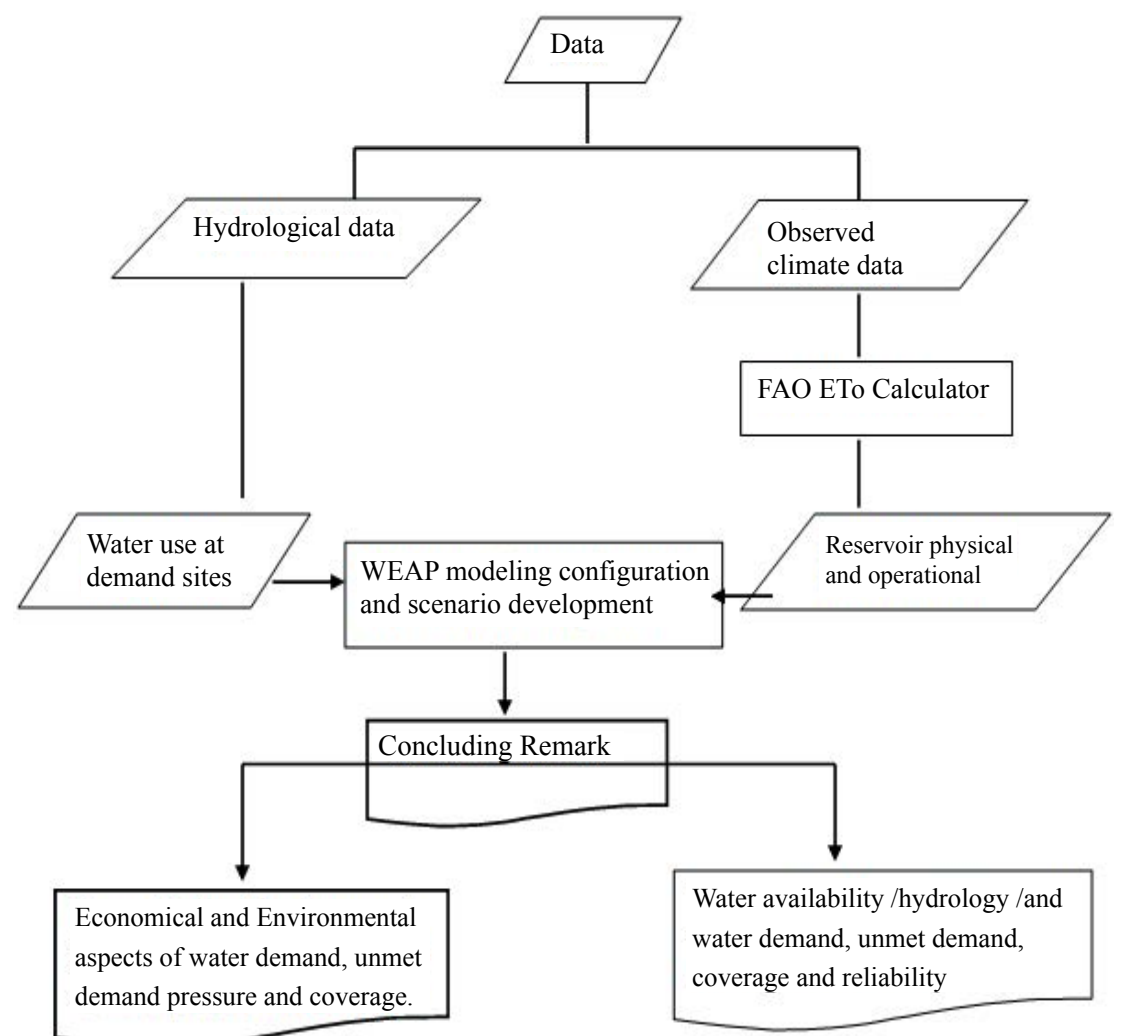

Figure 3: Conceptual framework for data processing systems in the study.

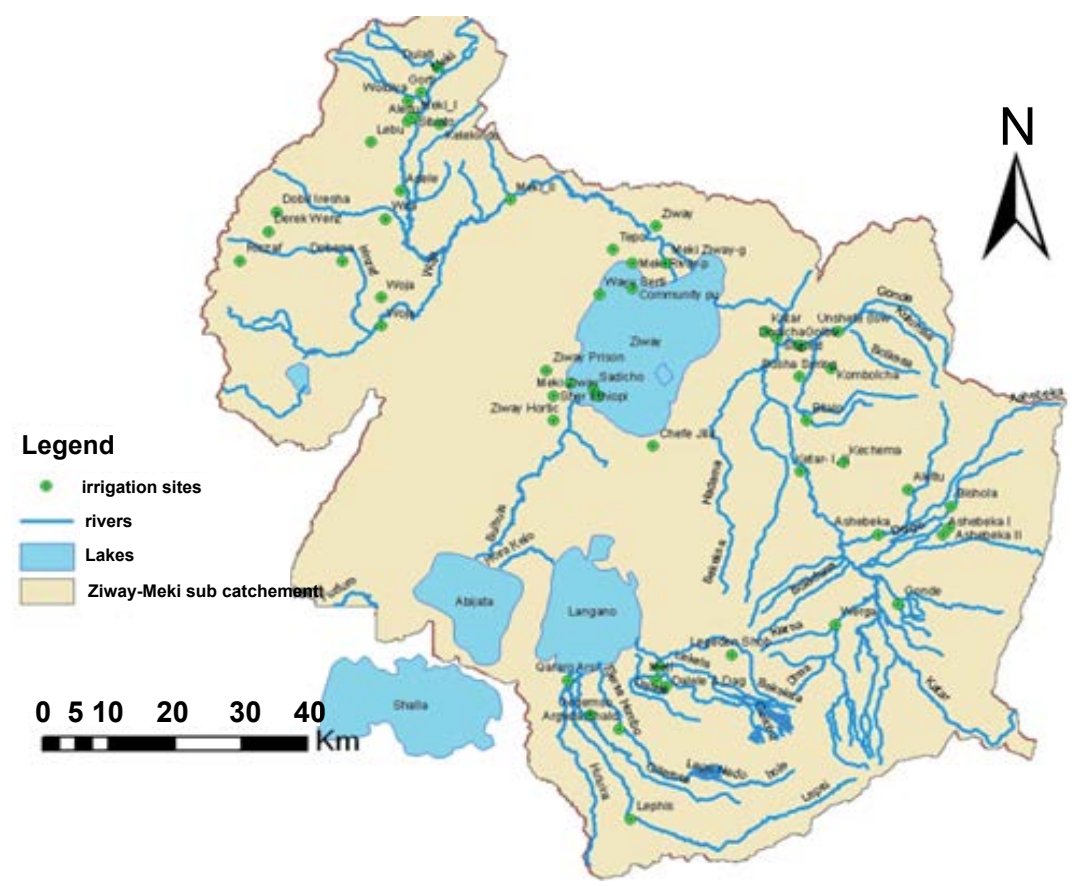

Figure 4: Existing irrigation potential sites in central rift valley lake basin.

- Scenario_1: Ongoing development Scenarios.

- Scenario_2: Likely Future Development scenarios.
Under this scenario the model runs with the existing demand sites situations which were combined into seven groups (the irrigation data for each is grouped based on their water source abstraction and lumped 
Citation: Shumet AG, Mengistu KT (2016) Assessing the Impact of Existing and Future Water Demand on Economic and Environmental Aspects (Case Study from Rift Valley Lake Basin: Meki-Ziway Sub Basin), Ethiopia. Int J Waste Resour 6: 223. doi:10.4172/2252-5211.1000223

Page 7 of 14

together as single demand site sources). Figure 4 explains the developed ongoing and the likely future development scenarios.

Hence, the schematic part of the first scenario (the Reference Scenario) has been reconfigured in order to include the planned development schemes which are underpinned in the baseline condition. The effect of an increase in irrigated land and a corresponding increase in amount of water use also applied to find out how they affect runoff and corresponding economical development of such increase in Small Scale Irrigation Expansion around Lake Ziway and Upstream of the lake (Ziway, Meki and Katar river areas) by assuming $0.05 \%$ rate in each year from the existing schemes (Figure 5).

\section{WEAP model input data analysis}

Estimated monthly water abstraction: For all irrigation sites is calculated based on $20 \%$ of the abstracted water is assumed to drain back (returned) to the system, through subsurface during irrigation.

Bulbula Minimum Flow Requirements $\geq$ The Tennant method (1976) was used to estimate environmental flows as a percentage of naturalised stream flow.

The minimum flow required to sustain the aquatic environment is expressed as a percentage of the mean annual flow, with different percentages used for wet and dry seasons. In stream flow requirement node was placed just after the Bulbula pumped Irrigation Scheme. This is to serve users downstream and flows to Lake Abyata through Bulbula River. Studies indicate that environmental flows vary from year to year, depending on rainfall, where it ranges from between $15.7 \%$ to $33.5 \%$ of the annual flow, in dry seasons going up to $78 \%$ of the natural river flow [10]. An intermediate value of $35 \%$ of mean monthly naturalized flows based on Tennant method [13] was used to estimate the in stream flow requirement node, Tables 3 and 4 below.

Five catchment sites generated using the FAO rainfall runoff method in WEAP, The land use and climate of a catchment site were defined. Figure 6 shows the schematic distribution or definition of the demand site in the WEA model to simulate the respective development scenarios.

\section{Results and Discussions}

\section{The impacts of development activities on stream flow (water availability) in the reference scenario}

Selected future development scenarios were modeled to determine the impact on water resources and to evaluate water resources availability with respect to water demand of the user sectors. The modelling of the existing water supply system has shown that irrigation poses the largest water demands in the Rift Valley Lake Basin system and that any significant change to irrigation demands are likely to have a significant impact on the sub basin and basin water resource availability and lake levels. Table 5 Summarizes the overall water balance availability assessment of WEAP results in Reference Scenarios (MCM).

The water availability of the areas is limited in the month of January $\left(17 \mathrm{Mm}^{3}\right)$ and December $\left(171 \mathrm{Mm}^{3}\right)$ and water shortage is observed in these months. On the other hand, in the other months the availability is efficient in the reference Scenarios. This is due to the fact that the inflow to the areas is dependent on the rainfall. The available water in the catchment are equally allocated to all development activities

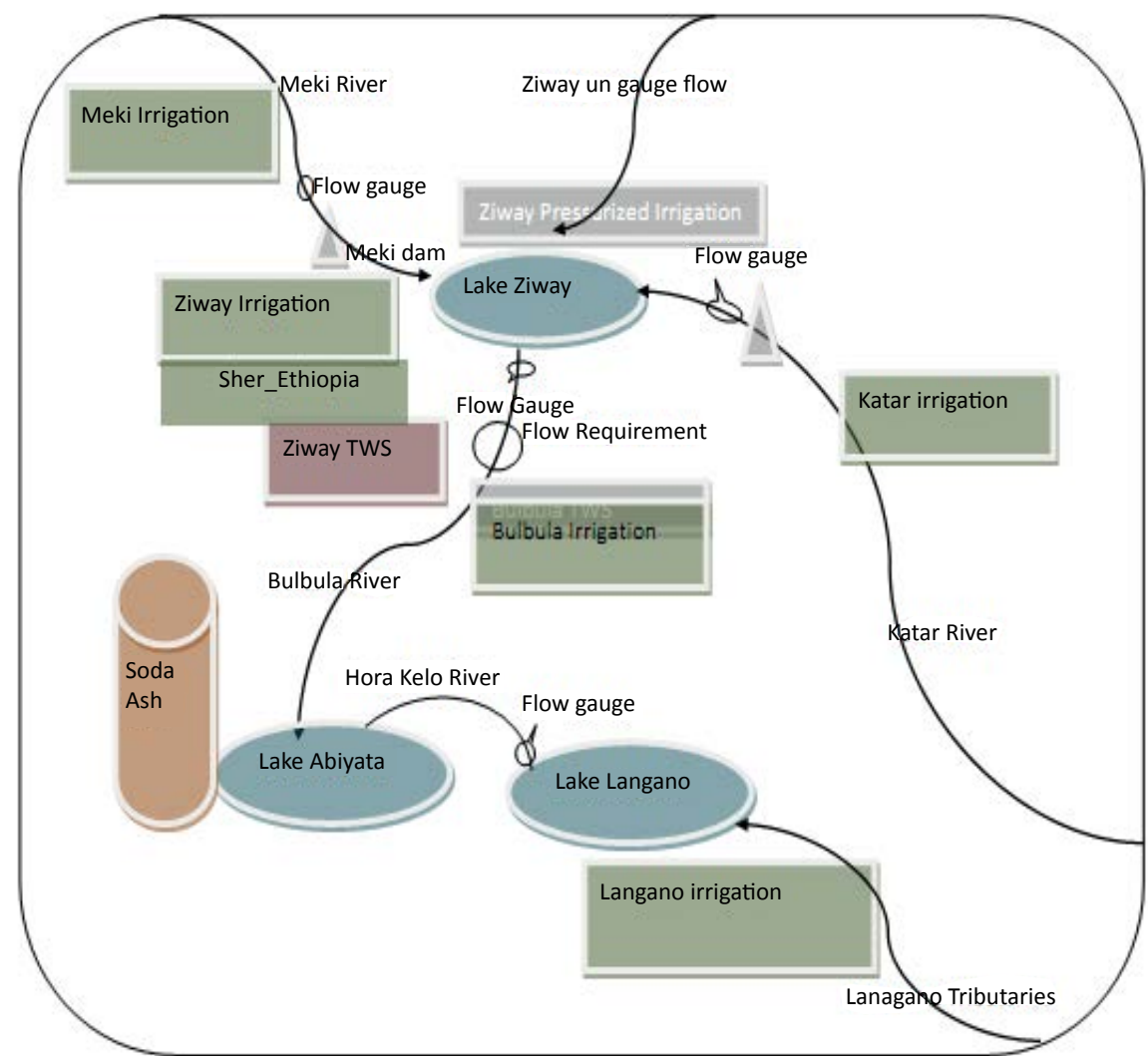

Figure 5: The model configuration for feasibility (ongoing development and likely future development scenarios). 
Citation: Shumet AG, Mengistu KT (2016) Assessing the Impact of Existing and Future Water Demand on Economic and Environmental Aspects (Case Study from Rift Valley Lake Basin: Meki-Ziway Sub Basin), Ethiopia. Int J Waste Resour 6: 223. doi:10.4172/2252-5211.1000223

Page 8 of 14

\begin{tabular}{|c|c|c|}
\hline Scenarios & WS, Industry & Irrigation scheme development \\
\hline Baseline (Reference) ( BLS) & Ziway TWS, Soda Ash & Existed situation \\
\hline Ongoing development (ODS) & Bulbula TWS & Ziway pressurized; Sher_Ethiopia Expansion; existed irrigation expansion \\
\hline Likely Future Development (LFDS) & Abyata Soda Ash Expansion & $(\mathrm{BLS})+(\mathrm{ODS})+$ Meki dam, Katar dam and diversion \\
\hline TWS: Town Water Supply & & \\
\hline
\end{tabular}

Table 3: Summary of the development scenarios.

\begin{tabular}{|c|c|c|c|c|c|c|c|c|c|c|c|c|}
\hline Naturalized $Q$ at Bulbula st ${ }_{n}$ in $\mathrm{m}^{3} / \mathrm{s} \%$ & 3.42 & 2.05 & 1.24 & 0.98 & 0.97 & 0.83 & 1.51 & 4.70 & 10.70 & 11.72 & 8.37 & 5.80 \\
\hline 60 & 2.05 & 1.23 & 0.74 & 0.59 & 0.58 & 0.50 & 0.91 & 2.82 & 6.42 & 7.03 & 5.02 & 3.48 \\
\hline 30 & 1.03 & 0.62 & 0.37 & 0.30 & 0.29 & 0.25 & 0.45 & 1.41 & 3.21 & 3.52 & 2.51 & 1.74 \\
\hline 10 & 0.34 & 0.21 & 0.12 & 0.97 & 0.09 & 0.08 & 0.15 & 0.47 & 1.07 & 1.17 & 0.84 & 0.58 \\
\hline
\end{tabular}

Table 4: Estimation of environmental flow downstream of bulbula irrigation scheme abstraction point based on tennant method.

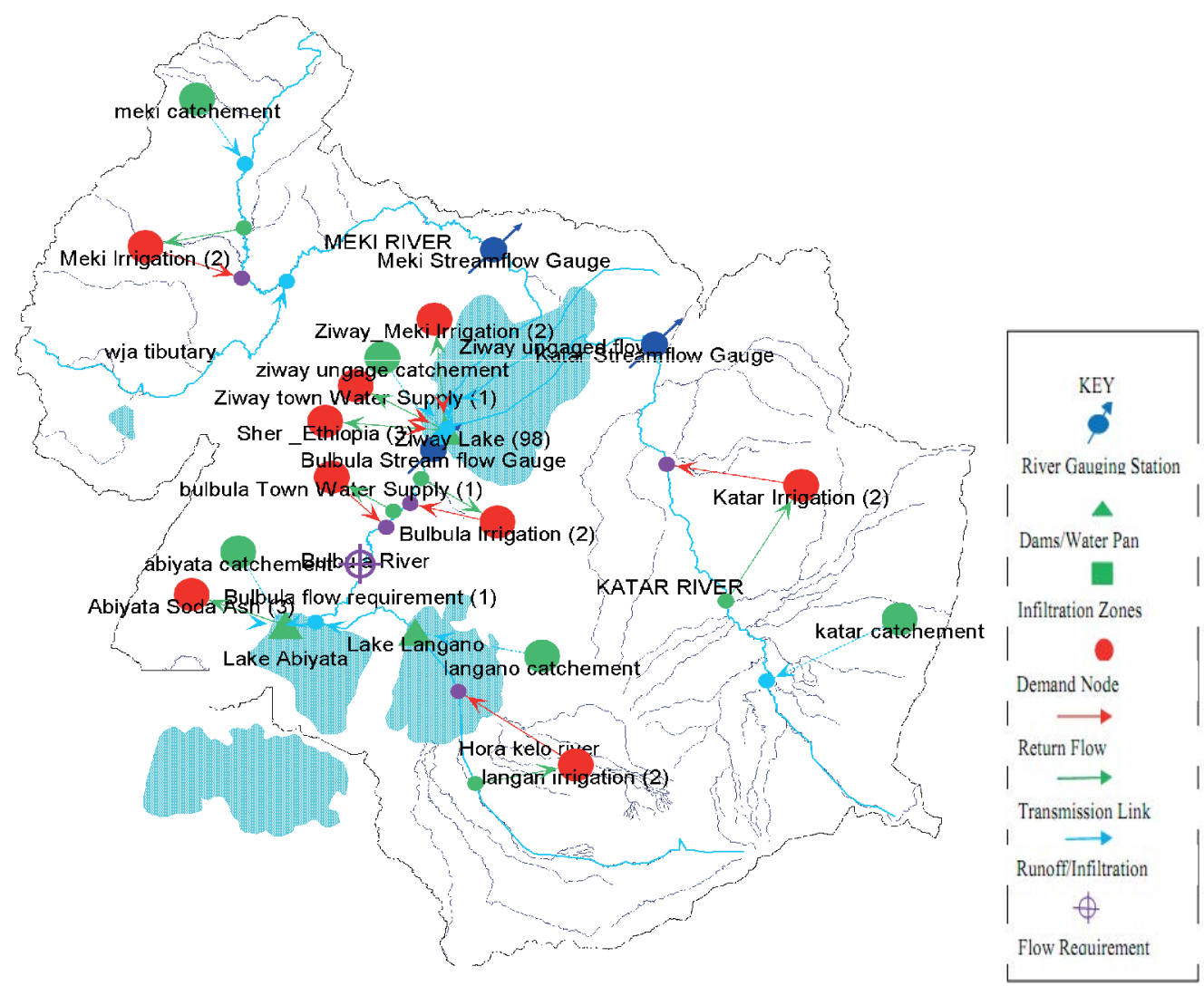

Figure 6: Schematic representations of the central rift valley catchment system and demand sites in WEAP21.

\begin{tabular}{|c|c|c|c|c|c|c|c|c|c|c|c|c|c|c|}
\hline Sources & Jan & Feb & Mar & Apr & May & Jun & Jul & Aug & Sept & Oct & Nov & Dec & Annual (sum) & Ave. \\
\hline Inflow to Areas $\left(\mathrm{Mm}^{3}\right)$ & 237 & 419 & 730 & 885 & 847 & 944 & 1440 & 1430 & 1060 & 520 & 191.5 & 188 & 8893 & 741.1 \\
\hline Out flow from Areas $\left(\mathrm{Mm}^{3}\right)$ & 254 & 403 & 661 & 789 & 718 & 922 & 1420 & 1410 & 1050 & 518 & 215 & 359 & 8790 & 732.5 \\
\hline Balance $\left(\mathrm{Mm}^{3}\right)$ & -17 & 15.9 & 69.2 & 95.5 & 66.0 & 22.0 & 20.3 & 16.10 & 9.25 & 1.71 & 24.5 & -171 & 103 & 8.58 \\
\hline
\end{tabular}

Table 5: Monthly average Inflows to areas and out flows from areas (MCM) in reference scenarios.

in the current situations and the remaining water that is not used is $103 \mathrm{Mm}^{3}$ and can be available in the system for further development with care implementation. No major changes are imposed in this scenario. Under these situations the available water resources in the area is sufficient for some careful implementation of projects except during dry seasons when the projects are dependent on rainfall during December and January.

\section{Unmet demand, demand coverage and demand reliability in the basin (reference scenarios)}

Unmet demand is defined as the quantity of water that cannot be physically delivered from the river during a certain period of the year. This situation is likely to deteriorate in the future due to the progression of water demand if no measures have taken to address them. The simulation with 
Citation: Shumet AG, Mengistu KT (2016) Assessing the Impact of Existing and Future Water Demand on Economic and Environmental Aspects (Case Study from Rift Valley Lake Basin: Meki-Ziway Sub Basin), Ethiopia. Int J Waste Resour 6: 223. doi:10.4172/2252-5211.1000223

Page 9 of 14

WEAP suggests that the requirements for the months of February to May will be difficult to be met in years that have hydrographs similar to where precipitation occurs late in the season and the peak flows appear in August to November with flows still quite low in February to May.

Water demand results cover requirements by and allocations to demand sites. Unmet demand, Coverage and Demand Reliability were considered in this study. Unmet demand is the amount of each demand site's requirement that is not met, and coverage is the percent of each demand site's requirement (adjusting for demand site losses, reuse and demand-side management savings) that is met, from $0 \%$ (no water delivered) to $100 \%$ (delivery of full requirement). Reliability is a measure of frequency or probability that a system is in a satisfactory state meeting a given criterion.

It is therefore necessary to carefully verify these results through further field surveys in order to ascertain the possible effects of data uncertainties and the extent to which water-users adopt alternative coping strategies.

In the reference (baseline) scenario, the demand of all users is $100 \%$ covered, except Langano irrigation site and Bulbula (Figure 7). In the case of Langano, irrigation demand is in average only covered between $33.33 \%$ and $86.5 \%$ during Feb to May (the unmet demand, 2.75 $\mathrm{Mm}^{3}$ ). While $95.2 \%$ (unmet demand, $0.11 \mathrm{Mm}^{3}$ ) volume covered in Bulbula. Here, seasonal variations of rainfall lead to varying flow of the tributaries in the Langano catchment while Bulbula is by out flow of Lake Ziway.

The demand reliability in the reference scenarios for all demand sites is $100 \%$ except Langano and Bulbula Irrigation demand sites. The demand reliability of both Langano and Bulbula irrigation sites has $92.15 \%$ and $66.67 \%$ reliably respectively.

\section{Water demand in the development scenarios}

As the graph indicates (Figure 8), the model ensured equitable allocation to the various users. This may not be the actual situation because, the catchment has minimal structures that regulate abstraction; therefore the model does not simulate the demand coverage accurately in such a system where the upstream users have 'priority' of use like Meki and Katar irrigation demand sites but as the result indicates, the water demand trend increasing is very high in the ongoing development scenarios in the areas of the downstream of Meki, Katar and around Lake Ziway.

In the table indicated that the simulated monthly average water demand in the ongoing scenarios increases from the reference (base line) scenarios. The ongoing scenarios indicated in Figure 9 show the higher increasing trend rather than the baseline, which will cause a significant water availability reduction in the future and will affect the economic and environmental situations of the basin.

\section{Water demand in the likely future development scenarios}

Under these development scenarios, the analysis includes the reference scenario, the ongoing scenarios and the projects, which are planned to be developed in the likely future scenarios.

The model output shows that there is a huge water demand in the areas in the likely future development scenarios which is linearly an increase state since the annual activity level in the areas increased linearly. Due to these there will be a critical impact on the water resources availability of the basin to fulfill their needs (demands) will impose exploitation of the basin. These trends observed in Ziway Pressurized irrigation, Katar irrigation diversion and Meki irrigation from dam and Ziway Meki irrigation demand sites.

\section{The comparison of water demand in all development scenarios}

The simulation result in the model (Figure 10) shows that there is high water demand in the likely future development Scenarios and ongoing development scenarios.

As Table 6 indicated annual activity level in the demand sites increases, the water demand also linearly increases. In the three developed scenarios, the change in water demand in the baseline and

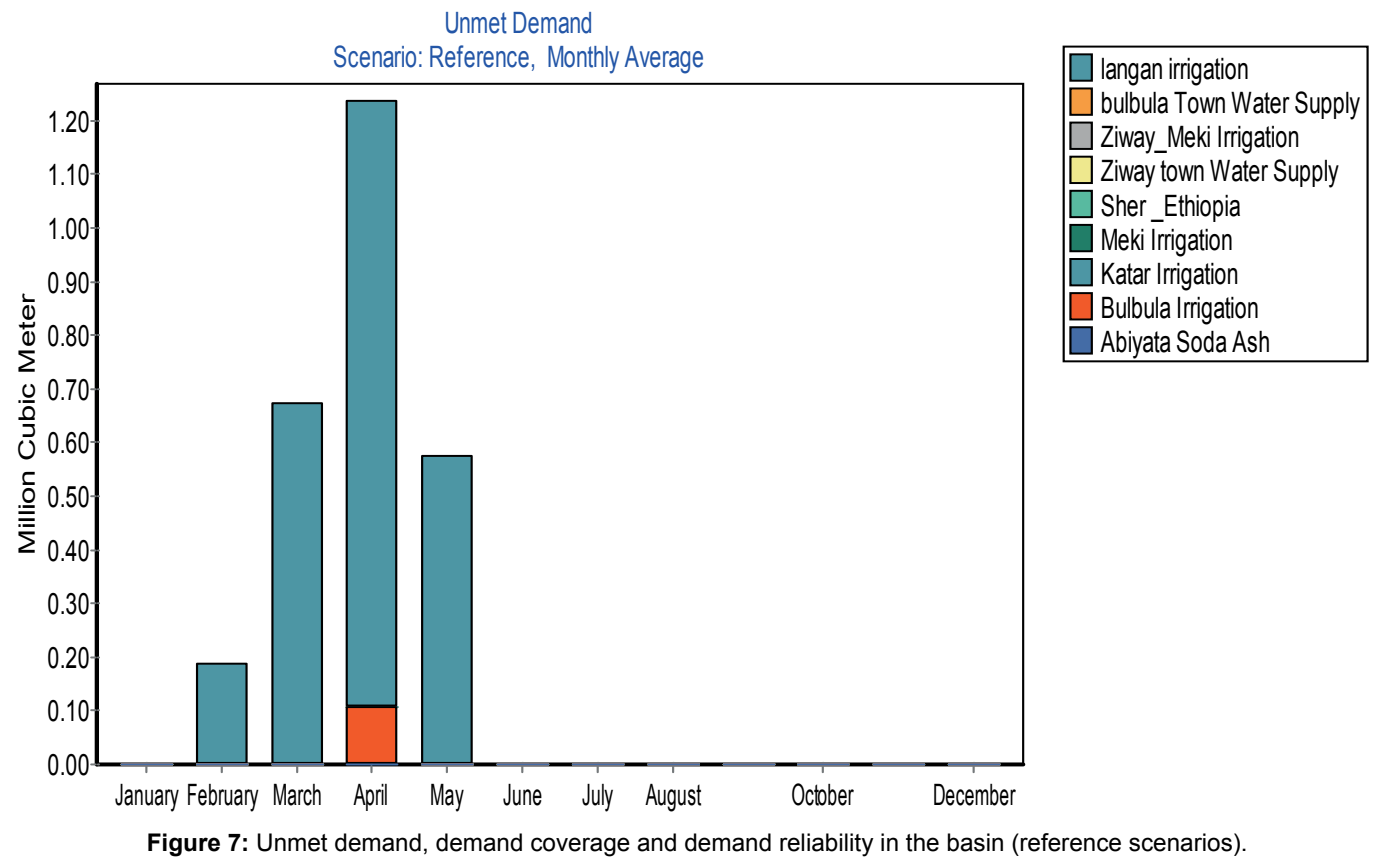


Citation: Shumet AG, Mengistu KT (2016) Assessing the Impact of Existing and Future Water Demand on Economic and Environmental Aspects (Case Study from Rift Valley Lake Basin: Meki-Ziway Sub Basin), Ethiopia. Int J Waste Resour 6: 223. doi:10.4172/2252-5211.1000223
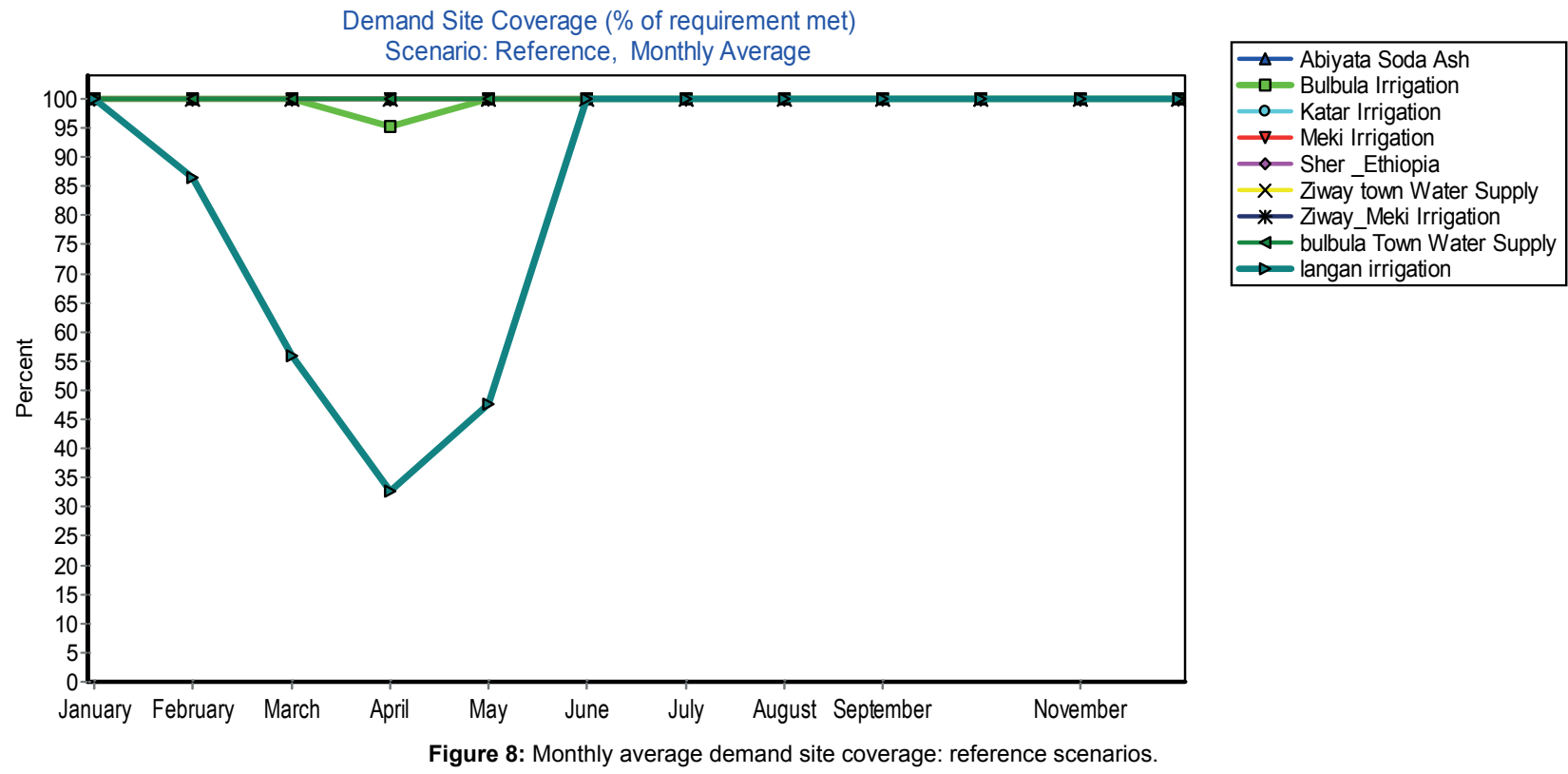

Figure 8: Monthly average demand site coverage: reference scenarios.

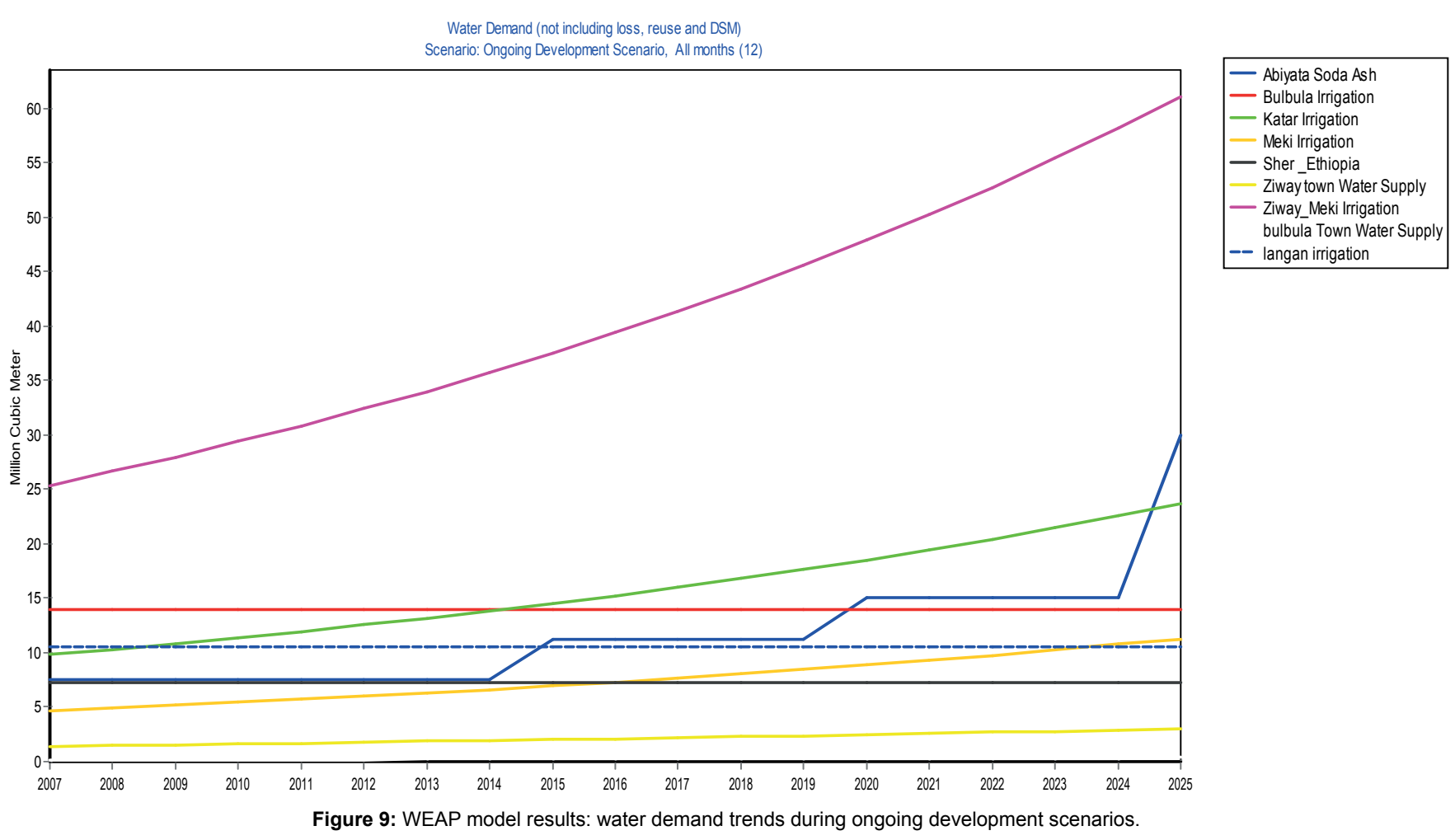

in future is a result of future development plan, infrastructure activities and are the major control. As indicted the table the annual increased water demand in each scenarios is $110.0,178.0$ and $239.0 \mathrm{Mm}^{3}$ in the base line, ongoing and likely future development scenarios respectively.

\section{Demand site reliability of the three development scenarios} (\%)

As Figure 11 shows that more reliability exploitation is observed during likely future Development Scenarios when compared to the other scenarios. The reliability exploitation demand sites in likely future development scenarios include Meki Dam, Katar Diversion, Sher_Ethiopia Expansion (51.75\%), Bulbula Irrigation (92.11\%) and Langano Irrigation Sites (66.67\%) are the main demand sites which have limited reliability rather than the ongoingdevelopment scenarios. Under these scenarios development most of the development projects will be failed economically if appropriate measurements are not taken like modernize irrigation technologies (drip and sprinkler irrigation methods). 

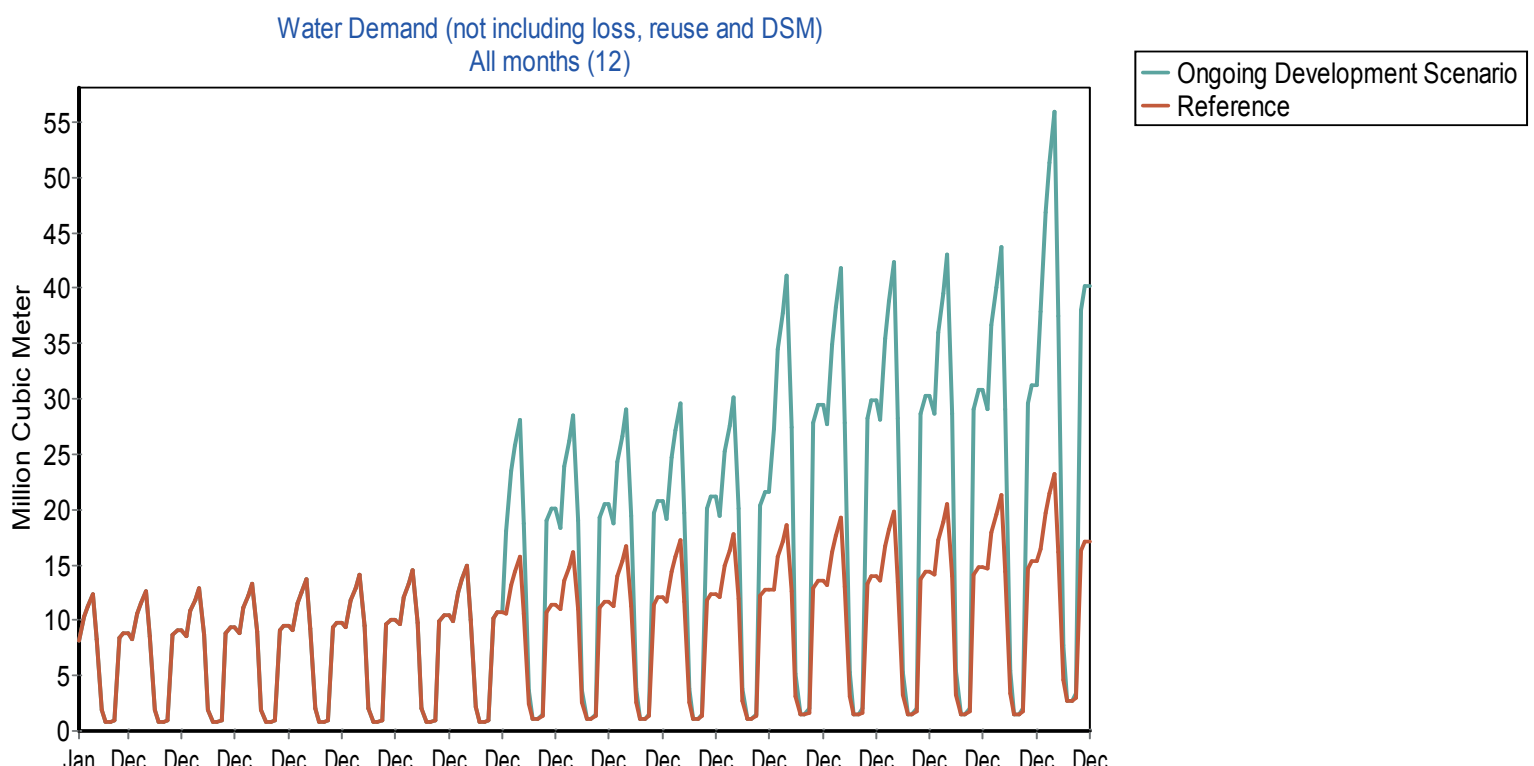

Jan Dec Dec Dec Dec Dec Dec Dec Dec Dec Dec Dec Dec Dec Dec Dec Dec Dec Dec Dec 20072007200820092010201120122013201420152016201720182019202020212022202320242025

Figure 10: Water demand trend in ongoing development scenarios vs. reference scenarios.

\begin{tabular}{|c|c|c|c|c|c|c|c|c|c|c|c|c|c|}
\hline Scenarios & Jan & Feb & Mar & Apr & May & Jun & Jul & Aug & Sept & Oct & Nov & Dec & Sum \\
\hline ODS & 18.1 & 23.01 & 25.2 & 27.5 & 18.3 & 3.62 & 1.15 & 1.15 & 1.49 & 18.6 & 19.7 & 19.7 & 178.0 \\
\hline Reference & 11.2 & 13.9 & 15.2 & 16.6 & 11.2 & 2.6 & 1.15 & 1.15 & 1.35 & 1.14 & 1.20 & 1.20 & 110.0 \\
\hline
\end{tabular}

Table 6: Monthly average water demands $\left(\mathrm{mm}^{3}\right)$ : ods \& reference scenarios.

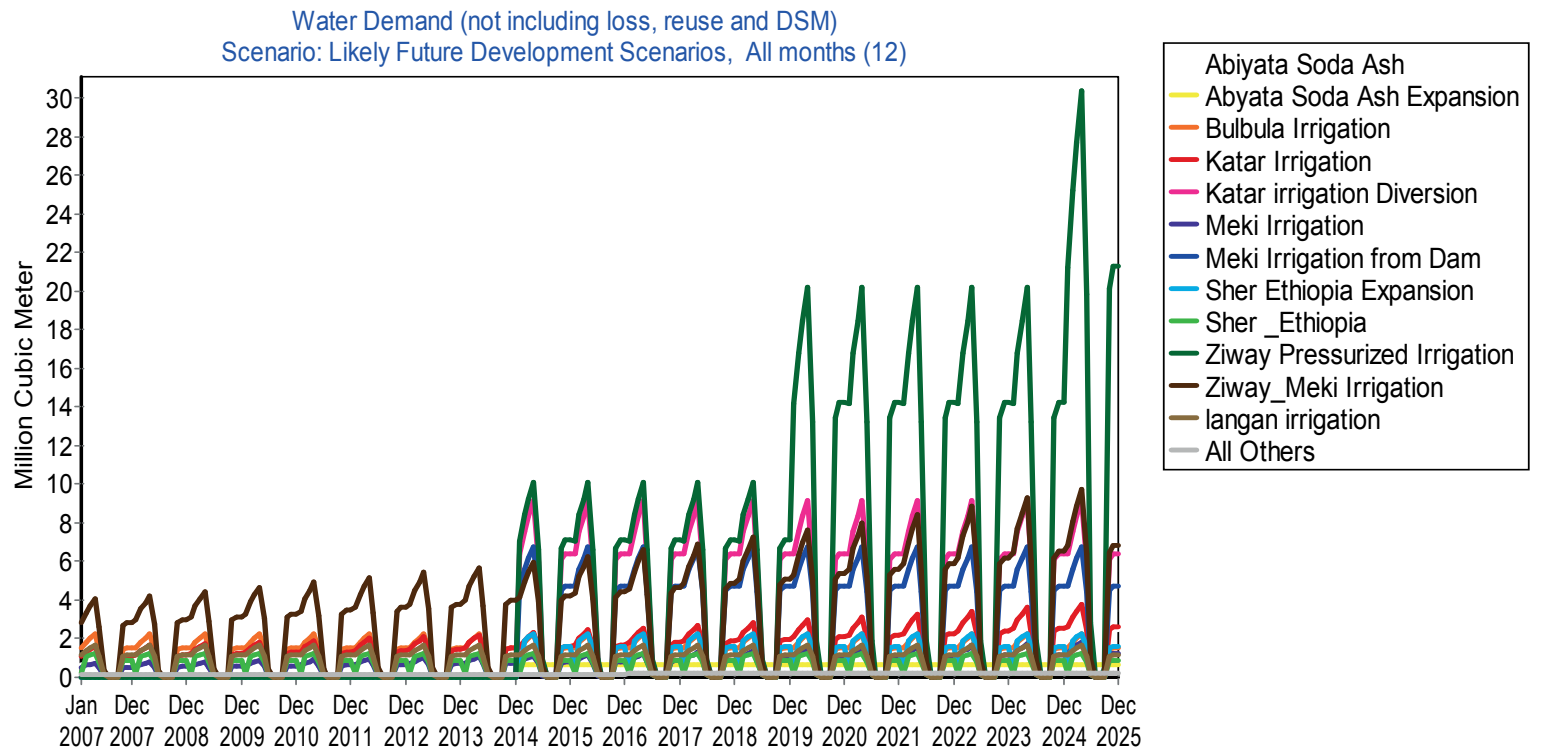

Figure 11: Water demand trend in the likely future development scenarios.

\section{Water demand pressures of the development scenarios on the economic and environmental aspects}

Economical aspects of the development scenarios: The availability of water in the reference scenarios will be economically efficient while in the ongoing and likely future scenarios this will reduce the economical product since the availability of water during these scenarios in irrigation areas is low ( shortage of water is observed from the simulation results). As the unmet demand is increases, the irrigation production will be limited (decreases) while if there is no unmet demand, there is a potential to economic development. As the result shows the ongoing and likely future scenarios the economical production in the planned projects will be in a reduction state or limited (Table 7).

Environmental aspects of the development scenarios: The 
Citation: Shumet AG, Mengistu KT (2016) Assessing the Impact of Existing and Future Water Demand on Economic and Environmental Aspects (Case Study from Rift Valley Lake Basin: Meki-Ziway Sub Basin), Ethiopia. Int J Waste Resour 6: 223. doi:10.4172/2252-5211.1000223

Page 12 of 14

\begin{tabular}{|c|c|c|c|c|c|c|c|c|c|c|c|c|c|c|c|c|c|c|c|c|}
\hline Scn & Jan & Feb & Mar & Apr & May & Jun & Jul & Aug & Sept & Oct & Nov & Dec & Sum \\
\hline ODS & $2.06 \mathrm{E}+05$ & $1.30 \mathrm{E}+06$ & $1.88 \mathrm{E}+06$ & $2.46 \mathrm{E}+06$ & $1.44 \mathrm{E}+06$ & $1.26 \mathrm{E}+05$ & 0 & 0 & $1.14 \mathrm{E}+04$ & $8.79 \mathrm{E}+05$ & $9.36 \mathrm{E}+05$ & $9.36 \mathrm{E}+05$ & $1.02 \mathrm{E}+07$ \\
\hline Ref & $1.19 \mathrm{E}-06$ & $1.88 \mathrm{E}+05$ & $6.73 \mathrm{E}+05$ & $1.13 \mathrm{E}+06$ & $5.76 \mathrm{E}+05$ & 0 & 0 & 0 & 0 & $8.06 \mathrm{E}-07$ & $1.03 \mathrm{E}-06$ & $1.03 \mathrm{E}-06$ & $2.57 \mathrm{E}+06$ \\
\hline Sum & $2.06 \mathrm{E}+05$ & $1.48 \mathrm{E}+06$ & $2.56 \mathrm{E}+06$ & $3.59 \mathrm{E}+06$ & $2.02 \mathrm{E}+06$ & $1.26 \mathrm{E}+05$ & 0 & 0 & $1.14 \mathrm{E}+04$ & $8.79 \mathrm{E}+05$ & $9.36 \mathrm{E}+05$ & $9.36 \mathrm{E}+05$ & $1.27 \mathrm{E}+07$ \\
\hline
\end{tabular}

Table 7: Monthly average unmet demand $\left(\mathrm{m}^{3}\right)$ in all demand sites: ods \& reference scenarios.

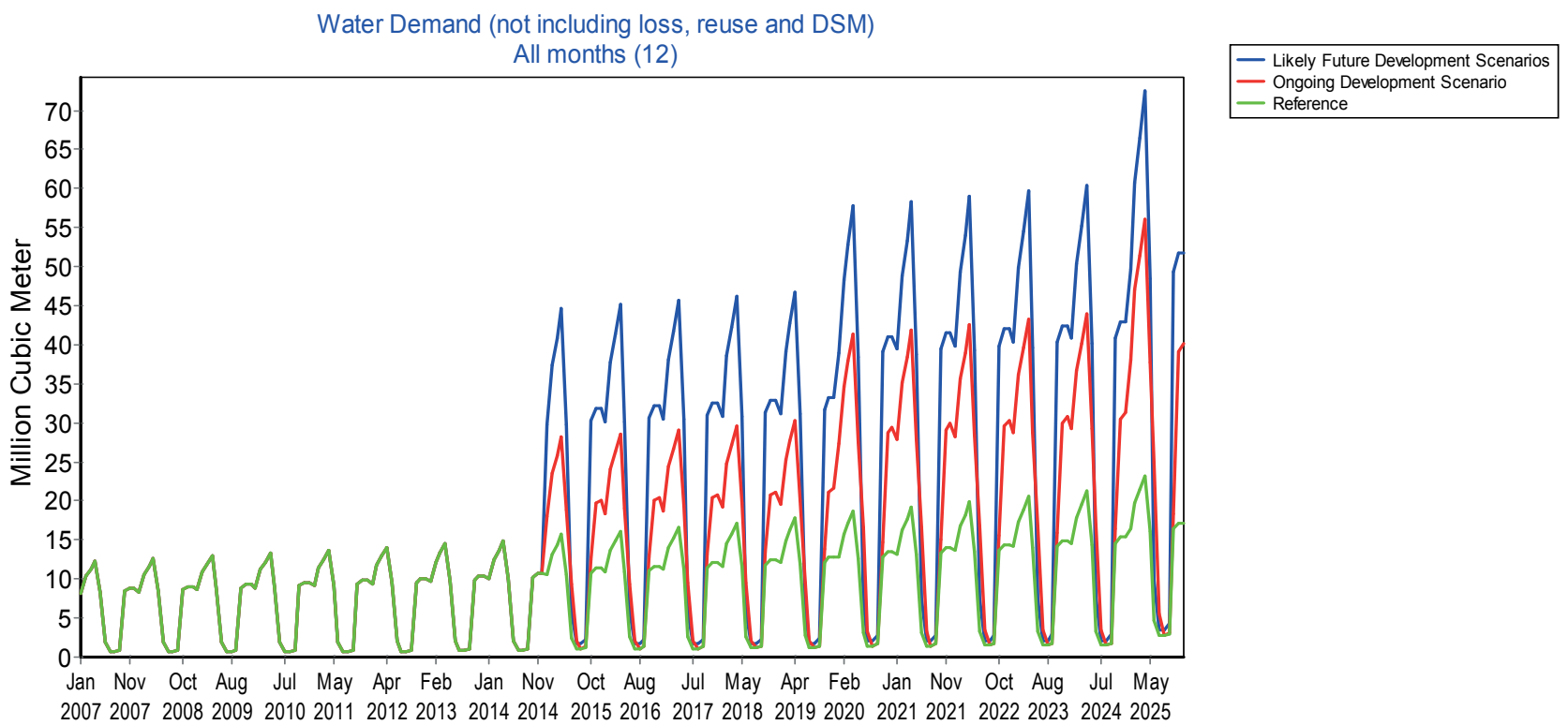

Figure 12: Water demand comparison of the reference, ongoing development and likely future development scenarios.

environmental influences of the basin is evaluated based on the Bulbula river flow requirement. Under these scenarios the environmental influences of the basin is evaluated based on the downstream of the basin, which is the Bulbula river flow requirement, the outflow of Lake Ziway. Based on these the amount of the flow requirement is calculated and evaluated with respect to the flow of the River Bulbula. As the result of the model output indicated that there is high fluctuate flow of the river (Figure 12).

The Bulbula flow fluctuated in the future scenarios when keeping the highest priority for the Bulbula River. This is due to upstream extension development projects are implemented. This situation is leads to influence the flow of Bulbula and ecology of the river and Lake Abyata, the production of Soda ash will be threatened (Figures 13 and $14)$.

\section{The Proposed Management Options and Adaptations}

The possible management solutions and adaptation options to be implemented are as follows:

- Water losses should be analyzed considering different spatial scales, and the unintended functions these losses may serve;

- Allocation principles should promote water users' willingness to invest in water infrastructure and to improve efficiencies and implementation of appropriate irrigation water management practices of surface irrigation systems to improve the water use efficiency (WUE),

- Adoption of efficient irrigation systems, which will yield the maximum crop productivity per unit volume of water (e.g. drip and sprinkler irrigation systems).
- Changing the crop variety, sowing date, crop density, and fertilization level studying water requirement and irrigation scheduling of major crops.

- Creating awareness among the people on efficient utilization of water and implementation of water pricing.

- Development of effective rainwater harvesting technologies, establishment and implementation of policy measures that govern the amount of water to be abstracted from the whole watershed.

- Consideration of climate change and its impact at all levels of water resource development projects from the planning up to the execution and management phases.

- Design and implementation of multipurpose water resource projects that have minimum environmental impact and can serve various sectors at the same time.

- Possible options are changes of the irrigation systems (sprinkler or drip irrigation systems instead of the current furrow irrigation systems in open field vegetable production) and in modification of current water management (better fine-tuning of water application with crop needs).

\section{Conclusion and Recommendation}

\section{Conclusion}

In the development scenarios a highly unmet demand is observed annually in LFDS $\left(72.4 \mathrm{Mm}^{3}\right)$ and $10.2 \mathrm{Mm}^{3}$ in ODS while $2.68 \mathrm{Mm}^{3}$ in the reference scenarios. Therefore the development scenarios in these 
Citation: Shumet AG, Mengistu KT (2016) Assessing the Impact of Existing and Future Water Demand on Economic and Environmental Aspects (Case Study from Rift Valley Lake Basin: Meki-Ziway Sub Basin), Ethiopia. Int J Waste Resour 6: 223. doi:10.4172/2252-5211.1000223

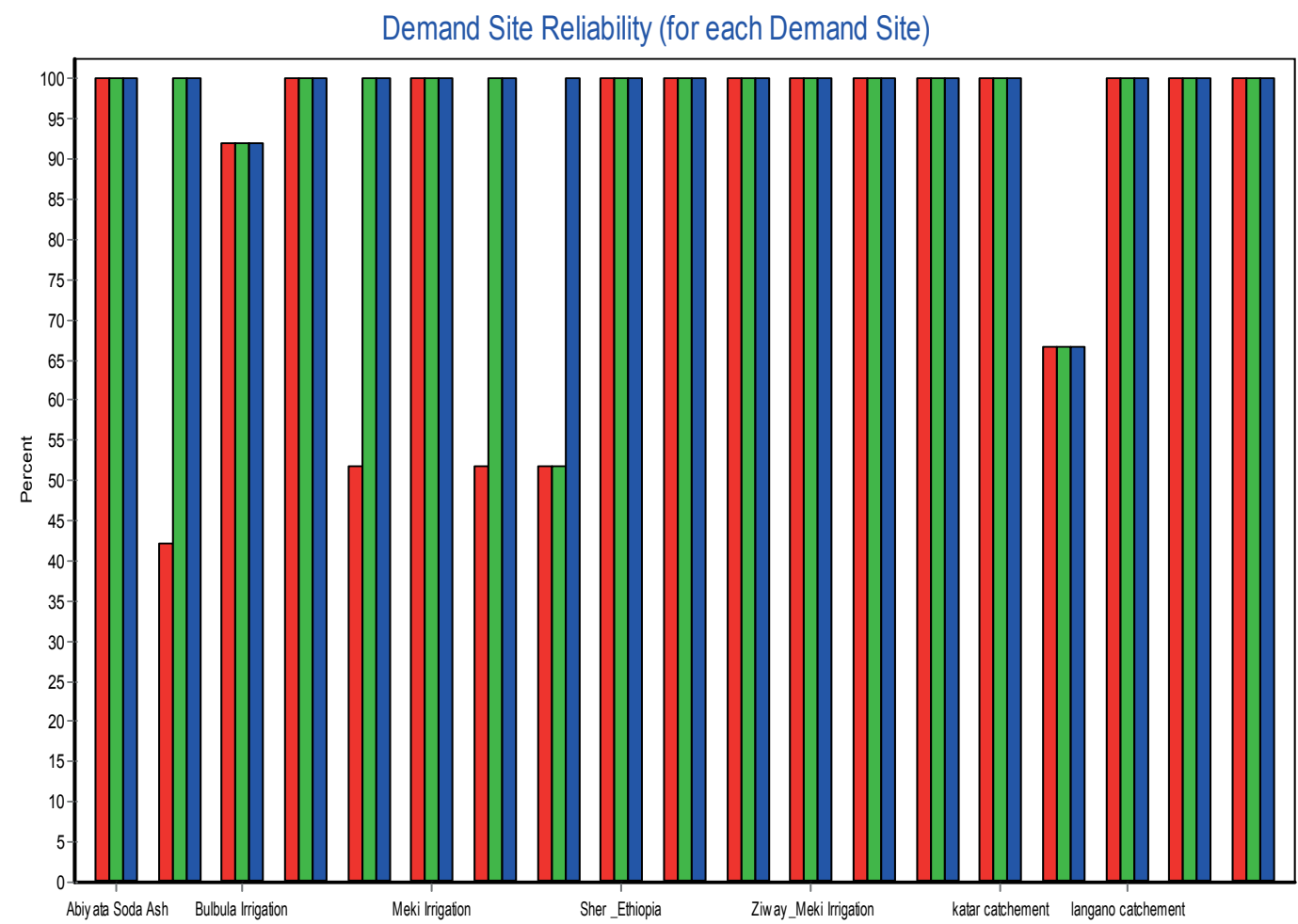

\begin{tabular}{|l}
$\square$ Likely Future Development Scenarios \\
$\square$ Ongoing Development Scenario \\
$\square$ Reference
\end{tabular}

Figure 13: The demand site reliability of the three development scenarios (\%).

Streamflow (below node or reach listed)

Scenario: Ongoing Development Scenario, All months (12), All Rivers (6)

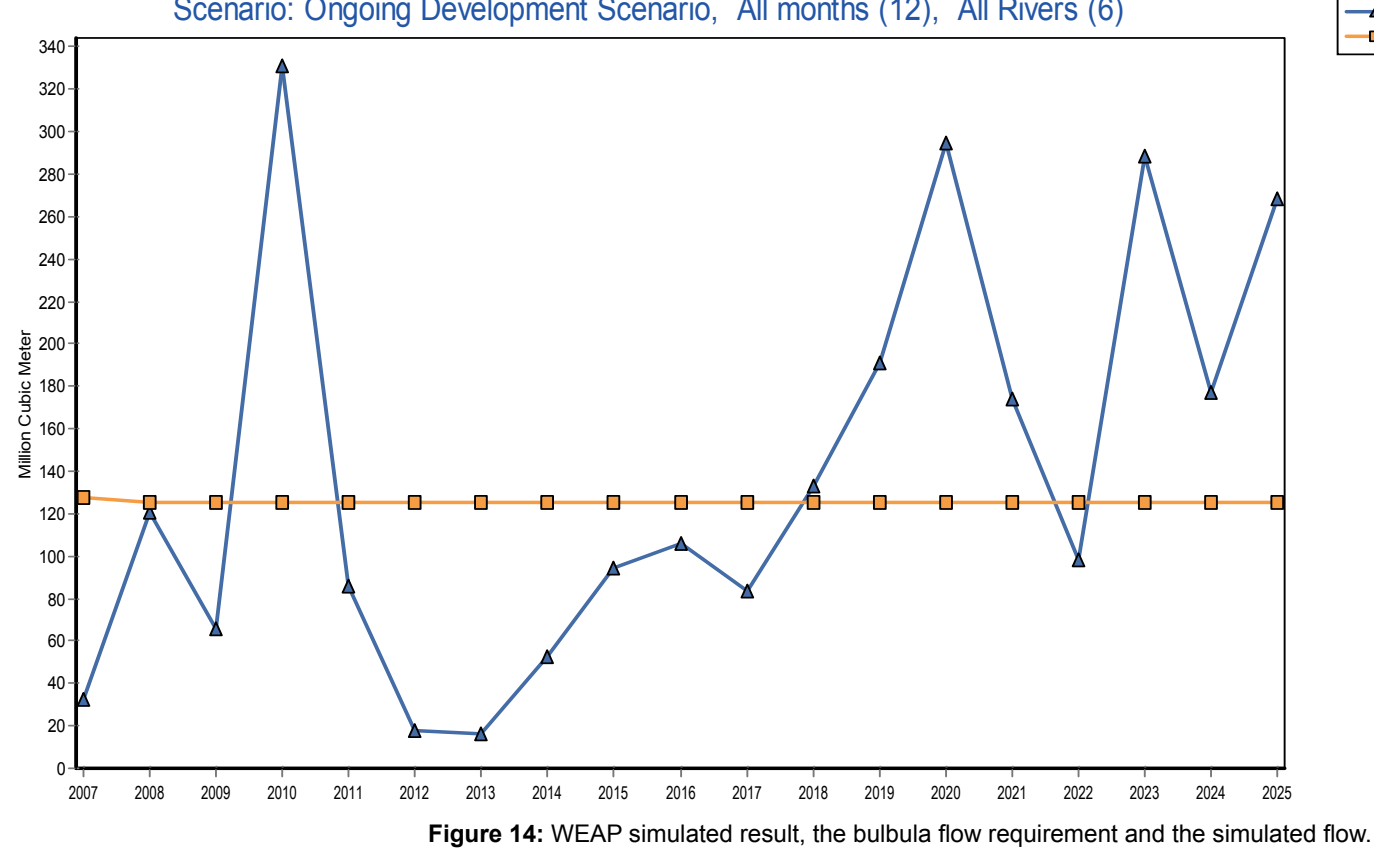

activities must be implemented based on the availability of the water with in allocation order that perform by WEAP to be efficient in water management (Table 8).

There must be a policy regulation during the development of projects in the near future especially the implementation of the Ziway Pressurized irrigation projects and the Meki-Katar dam and diversion projects.

The water demand volume of the development scenarios is critically 
Citation: Shumet AG, Mengistu KT (2016) Assessing the Impact of Existing and Future Water Demand on Economic and Environmental Aspects (Case Study from Rift Valley Lake Basin: Meki-Ziway Sub Basin), Ethiopia. Int J Waste Resour 6: 223. doi:10.4172/2252-5211.1000223

Page 14 of 14

\begin{tabular}{|c|c|c|c|c|c|c|c|c|c|c|c|c|c|}
\hline Scenarios & Jan & Feb & Mar & Apr & May & Jun & Jul & Aug & Sep & Oct & Nov & Dec & Sum \\
\hline Ref & 11.2 & 13.9 & 15.2 & 16.6 & 11.2 & 2.60 & 1.15 & 1.15 & 1.35 & 11.4 & 12.0 & 12.0 & 110.0 \\
\hline ODS & 18.2 & 23.1 & 25.2 & 27.5 & 18.4 & 3.62 & 2.05 & 1.25 & 1.36 & 12.4 & 19.3 & 19.7 & 178.0 \\
\hline LFDS & 24.9 & 31.0 & 33.9 & 37.1 & 24.7 & 4.86 & 3.51 & 2.51 & 1.98 & 25.1 & 26.4 & 26.4 & 239.0 \\
\hline
\end{tabular}

Table 8: Water demands in all development scenarios $\left(\mathrm{Mm}^{3}\right)$.

\begin{tabular}{|c|c|c|c|}
\hline Scenarios & Unmet Water Demand $\left.\mathbf{( M m}^{\mathbf{3}}\right)$ & costs (birrha-1) & water applied (m3ha-1) \\
\hline Ref & 2.6 & $0.42 \times 10^{6}$ & $10^{8}$ \\
\hline ODS & 10.2 & $6.63 \times 10^{8}$ \\
\hline LFDS & 72.4 & $4.71 \times 10^{9}$ \\
\hline
\end{tabular}

Table 9: Economical aspects of unmet water demand in irrigation water productivity in the development scenarios.

increase from reference scenarios $\left(110 \mathrm{Mm}^{3}\right)$ to ODS $\left(178 \mathrm{Mm}^{3}\right)$ and $239 \mathrm{Mm}^{3}$ in LFDS annually which are higher than the availability of the water resources of the basin $\left(103 \mathrm{Mm}^{3}\right)$ in the current condition scenario. Therefore a careful implementation projects and water management systems must be undertaken during these development scenarios [14-16].

Therefore, if the likely future development scenarios in the subbasin are fully implemented, there will be prolonged periods, of several years, during which water levels will be much lower than they would be naturally. Due to this the average surface water availability of the Catchment will decrease. This is likely to have significant impacts on the ecology of the Bulbula River and Abyata Lake and Lake Ziway will be a terminal lake (Table 9).

\section{Recommendations}

Since the livelihoods and wellbeing of many people are directly dependent on the ecological character of the ecosystems, river basins, very careful consideration needs to be given to determining how the water is best utilized.

Water allocation is arranged within cooperative organizations. Allocation of the available water between upstream and downstream areas is often a problem. Cooperation between ooperatives in these areas is often poor and need to be strengthening them.

A study should be conducted to determine water quality objectives and reserve flows for Bulbula River be determined in order to enhance proper management and regulation, especially when the new proposed dam projects in the upstream areas are completed during the likely future development scenarios periods.

In the study the uncertainty to relay on the outputs are likely to be, and a great deal of uncertainty surrounds such estimates. Analysts must always cope with a number of uncertainties in the valuation process. These gaps will cope by conducting sensitivity analysis and identifying the likely sources of uncertainty and also imagine the alternative futures. Update the result in each year to see the significant impacts.

\section{References}

1. Zbigniew W, Kundzwiez, Naginder SS (1997) Water, Drought and Desertification in Africa. Water resources publiication 240: 57-66.
2. Valipour M (2013) Necessity of Irrigated and Rainfed Agriculture in the World. Irrigat Drainage Sys Eng S9: e001.

3. Halcrow (2007) Rift Valley Lakes Basin Integrated Resources Development Master Plan Study Project. Ministry of Water Resource the Ongoing Master Plan, Ethiopia.

4. MoWR (Minstry of Water Resources) (1999) Ethiopian Water Resources Management Policy. SEI (Stockholm Environment Institute). WEAP: Water Evaluation and Planning System-User Guide. Stockholm Environment Institute, Boston, USA.

5. Ayenew (1998) The hydrogeological system of the Lake District Basin, Central Main Ethiopian Rift. PhD Thesis, Free University of Amsterdam. The Netherlands.

6. Halcrow (2008) Rift Valley Lakes Basin Integrated Resources Development master Plan Study Project. Ministry of Water Resource the Ongoing Master Plan.

7. Awulachew SB, Yilma AD, Loulseged M, Loiskandl WA, Ayana M, et al. (2007) Water Resources and Irrigation Development in Ethiopia. Colombo, Sri.

8. Akivaga (2010) Simulation and Scenario Analaysis of Water Resources Management in Perkera Catchment using WEAP Model.

9. Arafat (2007) Devloping an integrated water resources management model for Al-Far'a catchments.

10. MacCartney, Arranz (2007) Application of the Water Evaluation And Planning (WEAP) Model to Assess Future Water Demands and Resources in the Olifants Catchment, South Africa Working Paper, p: 116

11. Allen RG, Pereira LS, Raes D, Smith M (1998) Crop evapotranspiration - Guidelines for computing crop water requirements - FAO Irrigation and drainage paper 56, FAO - Food and Agriculture Organization of the United Nations, Rome.

12. WWDSE (2008) Ziway Irrigation Project. Final Feasibility Report. Annex-A Hydrology.

13. Tennant (1976) "Instream flow regimens for fish, wildlife, recreation and related environmental resources." Fisheries 1: 6-10.

14. Halcrow (1992) Reconnaissance Master Plan for the Development of the Natural Resources of the Rift Valley Lakes Basin. Ministry of water resources, Ethiopia.

15. Mann JL (2006) Instream Flow Methodologies: An Evaluation Of The Tennan Method For Higher Gradient Streams In The National Forest System Lands In The Western U.S. Master of Science Thesis, Colorado State University Fort Collins, Colorado.

16. McCartney (2010) Evaluation of current and future water resource development in the Lake Tana Sub-basin. 